\title{
China's transition to innovation and IT market
}

By Aravind Yelery* Associate Professor, Timeless Learning Technologies

\section{Introduction}

China is transforming from being global factory to global centre for innovation and IT industries. Chinese manufacturing industry was hit hard during the Asian crisis of 1997 and later in 2008 when global recession hit the Chinese manufacturing- based export industry (see Graph 1). The buyers from the developed countries refused to pull the stocks and the manufacturing towns faced harsh conditions (China Daily; 2008). Chinese manufacturing industry feeds 100 million of migrant workers. Chinese government had been working rigorously to evade any such catastrophe by pushing a soft skill industry model.

The 'global factory' model faces new competitive challenges as globalization transforms markets for technology and knowledge workers. This has forced China's policy makers and corporate strategists to seek ways to move beyond the 'global factory' model. China's decision to invest in R\&D-oriented innovation and policy is an indicator which underlies the growing centrality of IT industry in the Chinese economy. China is leading the electronic information industry and it is trying use the colossal base of IT infrastructure for developing soft skill

\footnotetext{
* The author is an Associate Professor in India-China relations at Timeless Learning Technologies and is also handling the activities of India-China Center as a Director. Dr Aravind Yelery is an alumnus of Jawaharlal Nehru University, New Delhi and he has unique experience of being part of the academic as well as the corporate world in China during the course of his four year stay in China.
} 


\section{AFRICAN \\ EAST-ASIAN \\ AFFAIRS \\ THE CHINA MONITOR}

business.

The shock of 2008 financial crisis turned Chinese leaders conscious to carry out structural adjustment to ensure that China is being shielded from any forthcoming financial crisis. In order to do that, China's dependence on manufacturing and it being a prime source of foreign currency was the major block to proceed.

The revival of IT industry is an important measure taken to adjust the industrial structure, that is to say, the development of IT industry has important strategic significance in the development of China's economy in the coming decades. IPR, R\&D funding and Education are the three important variables which will determine this transition of China's IT industry. All these three sectors are currently undergoing a drastic facelift.

China's 10th Five-Year Plan (2001-2005) identified software and IT as an important industry which is indispensable to China's economic progress, hence deserving of government promotion, along with more established industries such as computer manufacturing, telecommunications, laser, and aerospace (China Internet Information Centre; 2001). Chinese People's Political Consultative Conference (CPPCC) endorsed the 'New Strategic Restructuring Plan' in 10th Five Year Plan. The plan vowed to readjust the structure of its agriculture and rural economy, continue to beef up the IT industry, develop the service sector and give priority to high-tech industries (People's Daily; 2001). The transition was set in motion just before China's entry into WTO in late 2001 (Saxenian; 2003).

99 (c) Centre for Chinese Studies, Stellenbosch University

All Rights Reserved. 


\section{Graph 1: China's Monthly Export Amounts (Billion Dollars) Trends and Characteristics of Chinese Transition to IT industry}

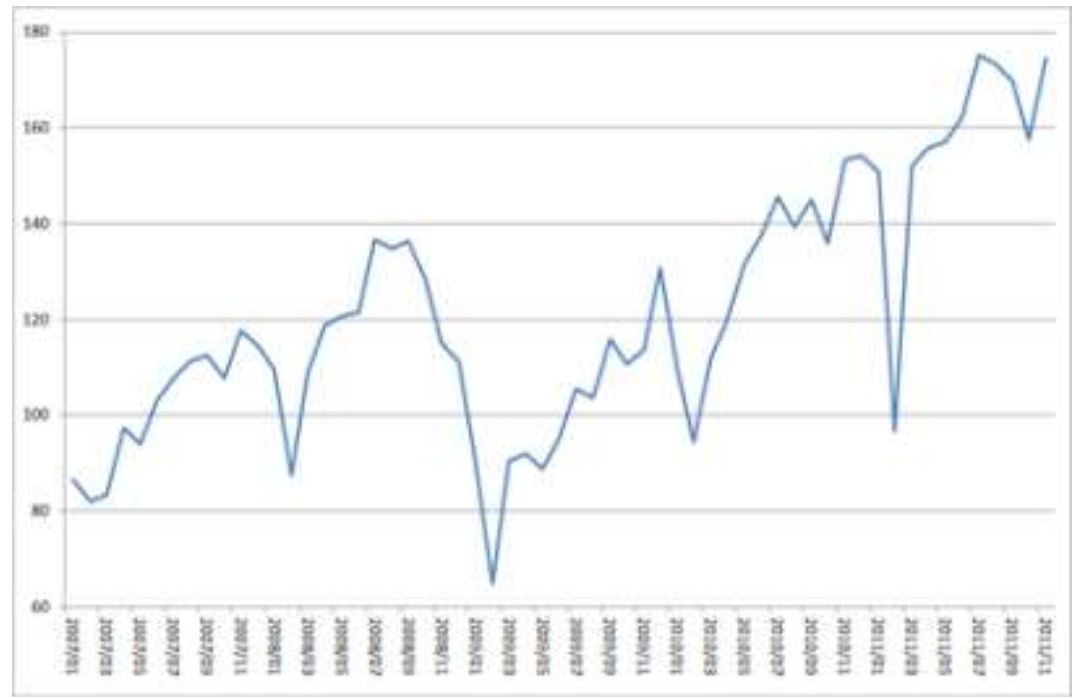

Source: China General Administration of Customs

China's subsequent five year planning highlighted the development of S\&T and thereof set to reinforce China's IT industry on a top priority. On 9 February 2006, the Chinese State Council issued the "Guidelines on National Medium-and Long-term Program for Science and Technology Development (2006- 2020)" (State Council PRC; 2006). As per the vision document, by 2020, the progress of science and technology is assumed to contribute 60 per cent or above to the country's development (State Council PRC; 2006: 12). If the plan follows its esteemed development track, by year 2020, China's reliance 


\section{AFRICAN \\ EAST-ASIAN \\ AFFAIRS \\ THE CHINA MONITOR}

on foreign technology is expected to decline to 30 per cent or below (State Council PRC; 2006). The guidelines set 11 major sectors under high priority category until 2020. The industries which came under this priority area includes mining resources, environment, agriculture, manufacturing, communications, transport, information industry, modern service industries, population and health, urbanization and urban development, public security, and national defence (State Council PRC; 2006: 11-12)

So far, IT industry has played a crucial role both in transforming China's industrial economy and in forging a peculiar Chinese model of developing a vibrant high-tech industry. On the backdrop of US-based researcher

International Data Corp's (IDC) (Beijing) prediction that the European debt crisis will worsen, and the decline in Chinese exports will become more pronounced in 2012, China's efforts to diversify its export components are explicable. The IDC report further states that the Chinese IT industry will continue to grow because of the government's plans to boost the high-technology sector during the 12th Five-Year Plan (2011-2015) period. The Chinese IT sector remains a vital area of government's investments (Yannan; 2011).

The Index released by the National Science Board's Science and Engineering Indicators 2010 indicates that the decade-long R\&D growth rate of China is consistent. India and China are the two developing countries which are leading in the S\&T sector and hold the key to world's technological advancement. As Graph 2 indicates, Asian growth varied from nearly 9 percent to 10 percent for India, South Korea, and 
Taiwan to more than 20 percent for China. This clearly indicates that China's R\&D spending is rising consistently. Increased public R\&D spending designed to support strategic policies aim to raise economic competitiveness through the development of knowledge-based economies (NSB; 2010: O-5).

\section{Graph 2: R\&D expenditures as share of economic output of selected countries: 1996-2007}

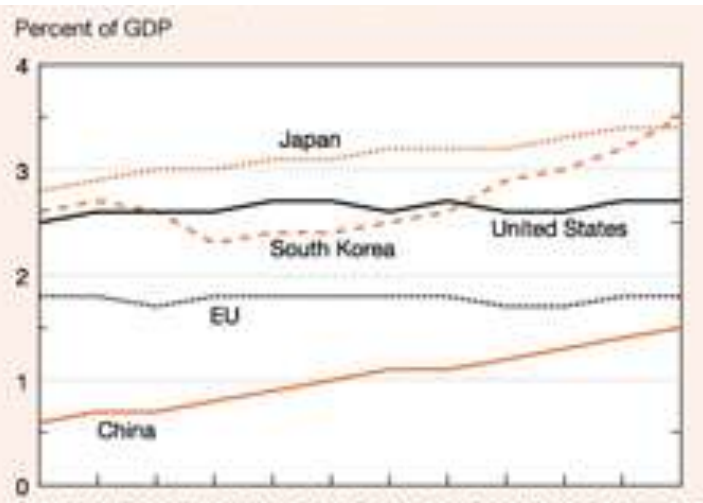

109619971908190920002001200220032004200520062007

Source: (National Science Board, Science and Engineering Indicators 2010: 25).

In 2011, as per the statistics available from Ministry of Industry and Information Technology (MIIT) (Govt. of China), China's fixed-asset investment in electronics and IT rose by 67.7 percent, year-on year. As China's SOEs are undergoing technological uplift the demand for IT recorded a growth of 30.5 per cent year-on-year in the first eight months of year 2011. IT has been identified as one of China's 'strategic 


\section{AFRICAN \\ EAST-ASIAN \\ AFFAIRS \\ THE CHINA MONITOR}

emerging industries' and innovation has been considered critical. In order to achieve this, education and innovation remain key areas where Chinese government is concentrating hard. Nurturing the talent becomes the foremost task. Various ideas were debated on how to make the optimum use of the available talent and plan to create a pool of engineers. 'Strengthening the nation with talent' (rencai qiang-guo) was one of the agenda items during China's Eleventh Five-Year Plan (20062010). The number of engineering graduates and software-application professionals has grown considerably in recent years (see Section 'Technical Education and Human Resource').

The example of Nanjing expo, which is regarded as the one of the two biggest annual IT events in China, is significant to underline city's plans to emerge as new Bangalore, carving a niche in global software industry. Chinese policies now focus on providing infrastructure, incentives for $\mathrm{R} \& \mathrm{D}$, and strengthening legal framework to protect the innovative ideas by stringent intellectual property rights and standards.

Policies to protect intellectual property rights (IPR) in China and China's indigenous innovation policies are equally decisive to ensure China's rise in the

IT industry. Recently China's efforts to encourage protection of IPR played a crucial role in "respecting creative work and igniting innovation and a key part in building of a country under the rule of law and credible society. To construct innovation-based country and improve socialist market economy system, it is a must to unswervingly protect IPRs" (People's Daily; 2011). It is observed that firms in industries where innovations are patented, have higher innovation 
intensity and are also more likely to be highly innovative. China has been driving the patent efforts rigorously to create a safe market competition. In the $11^{\text {th }}$ Five year plan of China, special efforts were made to raise the effective-ness about IPR in domestic as well as international Chinese industries. Though China's patent system was established in 1985, it reached a momentum since 2000. In the first decade of the 21 st century, patent applications in China grew by an average annual rate of 22.3 percent (WIPO; 2010). Graph 3 explains this trend.

\section{Graph 3: Innovation and IPR}

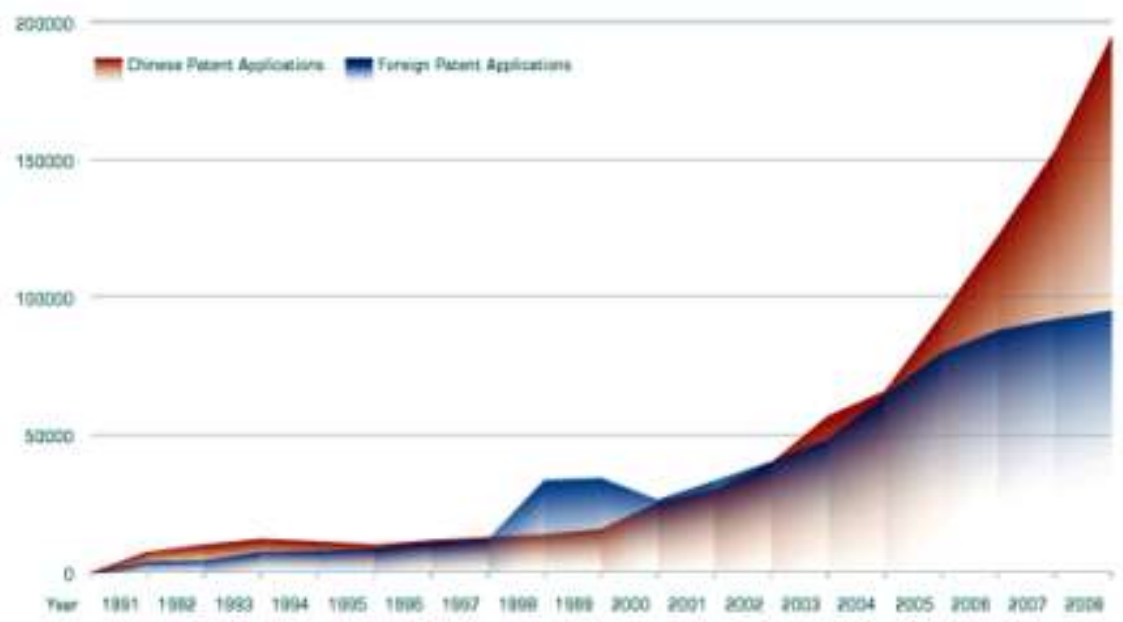

Source: World Intellectual Property Organization. 2010. Online: http:// www.wipo.int/wipo_magazine/en/2010/06/article_0010.html. 


\section{AFRICAN \\ EAST-ASIAN \\ AFFAIRS \\ THE CHINA MONITOR}

In 2009, China became the fifth largest user of the Patent Cooperation Treaty (PCT), filing just under 8,000 international patent applications which represents a growth rate of 29.7 percent (WIPO; 2010). As per the data available from State Intellectual Property Office of the PRC (SIPO), domestic valid patents maintain rapid growth and the structure thereof are significantly optimized. With domestic invention patents' share of the total rising from 33.3 percent in 2006 to 45.7 percent in 2010, these valid patents are a strong force to boost China's transformation in to IT powerhouse.

\section{Technical Education and Human Resource}

China's higher education is undergoing massive change to inculcate 'Innovation potential' as an essential step in systematic reform. This will be critical for developing the required intellectual capital as well as in laying the foundation for effective collaboration between industry and educational institutions. As per Chinese Ministry of Education's agenda, Higher Educational Institutions (HEI) are crucial in creating a talent pool as well as constructing the science parks, establish high-tech enterprises run by HEIs and combine industry, teaching and research together to turn the scientific and research outputs into productivity. The National Bureau of Statistics (NBS) disclosed in its series report that in 2010, China's higher education institutions of various forms had about 31 million students, about 8 million more than in 2005 and about 1 million more than the planned scale, indicating an increase of 35 per cent (People's Daily; 2011).

The school life expectancy in China has progressed consistently. As a result, higher education sector is providing the innovation impetus for 
China's fast development. In 2009, the total funding for research in universities was 11 billion US dollars. 70 percent of the winners of 2010 China National Natural Science Awards, National Technology Innovation Awards and National Science and Technology Progress Awards were from universities (Pan; 2011). Thus for China Educational reforms are carried out enabling Innovation led IT industry growth in the country. As per the statistics from the Science and Engineering Indicators 2012 (see Graph 4), number of Chinese students earning doctoral degrees in the field of natural science increased since 2000. As per the statistics available in 2009, China produced third highest numbers of $\mathrm{PhD}$ holders in natural sciences. Whereas, China topped the list of doctoral degrees in the field of engineering (see Graph 4).

\section{Graph 4: R\&D and Indigenous Innovation policy}
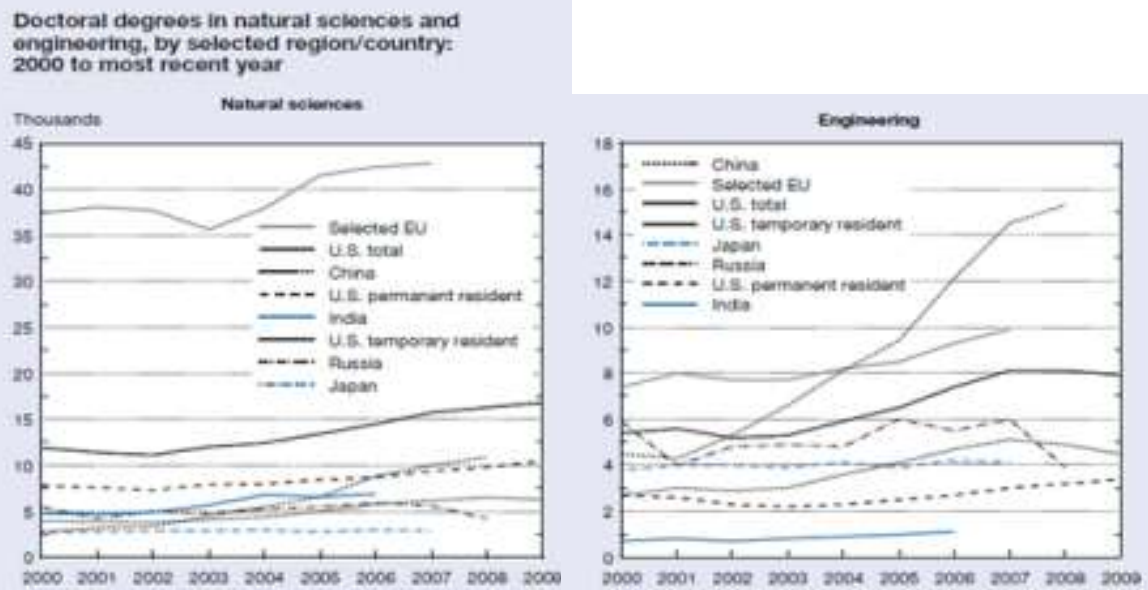

Bu - flaropaan Union

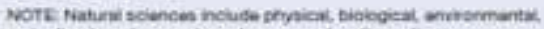

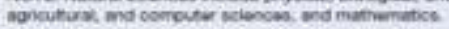

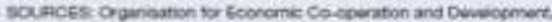

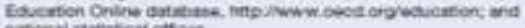
nafonal atanaticat otsoces. 


\section{AFRICAN \\ EAST-ASIAN \\ AFFAIRS \\ THE CHINA MONITOR}

Chinese government is giving special importance to R\&D in Science and Technology to increase its presence in China. China is considering reforming the funding programme to encourage more participation in R\&D in the IT. As shown in the Graph 2, over the past decade and half, the Central government spending on science and technology development had grown by around 20 percent annually. Given China's growing expenses on S\&T, it is becoming necessary to bring flexibility in allocating government funds to researchers and allow them to be used to pursue independent research projects.

In her recent statement at the national conference on science and technology work, State Councillor Liu Yandong, emphasized that China needs to reform funding methods for scientific and technological research in order to boost the nation's innovation capabilities. She also insisted that the management of the government-funded research projects should also be reformed (Xinhua 2011). Successful cloning, manned space flight, moon exploration and super-computers in China show the rising Innovation activity and awareness in China as well as the need to continuously and publicly encourage this trend as a key enabler in China's economic growth and competitiveness.

Since 2002, that is years before becoming the part of China's National Medium- and Long-Term Program for Science and Technology Development (2006-2020), the stringent government procurement policies provided security as well as boost-up to domestic IT companies. Although the policies communicating the rationale behind buying indigenous hardware were regulated through state and local policies, in 2006 it officially appeared in the so called landmark document of 
National Medium- and Long-Term Program for Science and Technology Development (2006-2020) (State Council, PRC, 2006).

\section{Conclusion}

China is changing its development model. The shift is strategic in a sense that it is diversifying export components, upgrading educational parameters, stream-lining the innovation techniques and adopting them quickly. China is building soft skill infrastructure to create a competent knowledge society.

Building an innovation-oriented country is therefore a major strategic choice for China's future development. China is eying to make it the prime component of country's GDP by 2020. As per the recent reports by Ministry of Industry and Information Technology (MIIT), revenues of China's software and information technology (IT) service industry rose 32.4 per cent year-on-year to 1.84 trillion Yuan (292.23 billion U.S. dollars) in 2011 (Xinhua, 2012).

This also indicates that China is shifting its target from manufacturing base of high-tech goods to a credible software giant. The report reinforcing this view points out that China's software exports increased 18.5 per cent from a year earlier to 30.4 billion U.S. dollars last year (2010). Another add on factor for China was its domestic consumption, at $\$ 8.1$ billion in 2009, China's domestic IT services market was bigger than India's $\$ 5.8$ billion (D’Altorio, 2010). Software and IT business is the best option for Chinese to avoid over dependence on manufacturing industry and as the most effective tool to reduce environmental degradation without affecting standard of living. Not in distant future, Chinese companies would be competing with Indian IT giants to control 


\section{AFRICAN \\ EAST-ASIAN \\ AFFAIRS \\ THE CHINA MONTOR}

Issue 1

August 2012

this ever expanding market. China sees bright future for both, its soft skill industry and its overall market share by 2020 .

\section{References}

China Daily. 2008. "Migrant workers seek greener pastures" China Daily, 17 December. Online: http://www.chinadaily.com.cn/business/2008-12/17/ content 7313079.htm. Accessed: 29 February 2012.

China Internet Information Center. 2001. "Look into the Next Five Years," China.org.cn. N.d. Online: http://www.china.org.cn/e-15/index.htm. Accessed: 29 February 2012,

D’Altorio, T. 2010. “China's IT Services Industry Challenges India in Outsourcing," Investment U. 14 September. Online: $\underline{\text { http:// }}$ www.investmentu.com/2010/September/chinas-information-technologyservices-industry.html. Accessed: 29 February 2012.

National Science Board (NSB). 2010. Science and Engineering Indicators (SEI) Report 2010. National Science Foundation, Arlington. pp. O-5.

National Science Board (NSB). 2012. Science and Engineering Indicators (SEI) Report 2012. National Science Foundation, Arlington. pp. O-8.

PAN, H. 2011. "The Role of Higher Education in China's Development." Speech by H.E. Ambassador at Bunda College of Agriculture, 8 April. Online: http://mw.china- embassy.org/eng/sghdhzxxx/t813567.htm. Accessed: 26 February 2012.

People's Daily. 2001. "CPPCC Members Hail New Strategic Restructuring Plan," 7 March. Online: http://english.peopledaily.com.cn/200103/07/ eng20010307_64346.html. Accessed: 26 February 2012.

People's Daily. 2011. “China's higher education students exceed 30 million,” 11 March. Online: http://english.peopledaily.com.cn/90001/98649/7315789.html. 
Accessed: 26 February 2012.

The State Council - PRC. 2006. The National Medium- and Long-Term Program for Science and Technology Development (2006-2020)

Saxenian, A. L. 2003. "Government and Guanxi: The Chinese Software Industry in Transition", University of California at Berkeley.

World Intellectual Property Organization Magazine (WIPO Magazine). 2010. "China's IP Journey", December. Online: http://www.wipo.int/wipo magazine/ en/2010/06/article_0010.html. Accessed: 29 February 2012.

Xinhua News Agency. 2011. "Reforming funding system vital to China's innovation capacity: officials, researchers," 18 February. Online: http:// news.xinhuanet.com/english2010/china/2011-02/18/c 13739089.htm. Accessed: 26 February 2012.

Xinhua News Agency. 2012. "Software, IT service industry revenues up 32.4\%," 26 February. Online: http://www.china.org.cn/business/2012-02/26/ content_24734506.htm. Accessed: 26 February 2012.

Yannan, T. 2011. "Chinese IT market set to surge," 23 December. Online: http://news.xinhuanet.com/english/china/2011-12/23/c 131323502.htm. Accessed: 26 February 2012. 